\title{
Exoproteolytic activity determined by flow injection analysis: its potential importance for bacterial growth in coastal marine ponds
}

\author{
Daniel Delmas, Catherine Legrand, Christian Bechemin and Cécile Collinot \\ CREMA - L'Houmeau, CNRS'IFREMER, case 5, 17137 L'Houmeau, France.
}

Received December 30, 1992; accepted June 30, 1993.

Delmas D., C. Legrand, C. Bechemin, C. Collinot. Aquat. Living Resour., 1994, 7, 17-24.

\begin{abstract}
The measurement of the fluorescent 4-methyl-7-coumarinylamine released from the hydrolysis of a nonfluorescent peptide model substrate by exoproteolytic enzymes has been adapted to flow injection analysis (FIA). FIA allows samples to be processed very quickly (less than 2 min. for triplicate determinations) with good sensitivity $(<0.1 \mu \mathrm{M})$ and reproducibility (relative standard deviation $<3 \%$ at the $0.2 \mu \mathrm{M}$ level). In a coastal marine pond, exoproteolytic activity was closely related to bacterioplankton biomass. The high activity measured in pond water (maximum velocity: $V_{M} \approx 1.46$ to $2.54 \mu \mathrm{M} \cdot \mathrm{h}^{-1}$ ) emphasizes the importance of dissolved protein hydrolysis for bacterial growth and for dissolved organic nitrogen cycling. The mean turnover time of dissolved peptides was 7.6 days, and amino acids liberated by exoproteolytic activity could potentially support, on average, $40 \%$ of the bacterial nitrogen demand.
\end{abstract}

Keywords: Flow injection analysis, exoproteolytic activity, dissolved protein, bacterioplankton, coastal marine pond.

Activité exoprotéolytique mesurée en flux continu : importance potentielle pour la croissance des bactéries dans les marais maritimes.

Résumé

La mesure du fluorochrome 4-méthyl-7-coumarinylamide, libéré par l'hydrolyse exoprotéolytique d'un substrat peptidique non fluorescent, a été automatisée au moyen d'un système d'analyse en flux continu. Cette technique permet l'analyse très rapide des échantillons (moins de 2 minutes pour des triplicats) avec une bonne sensibilité $(<0,1 \mu \mathrm{M})$ et une bonne reproductibilité (coefficient de variation $<3 \%$ pour des concentrations supérieures à $0,2 \mu \mathrm{M}$ ). Dans un marais maritime, l'activité exoprotéolytique est étroitement liée à la biomasse bactérioplanctonique. Le haut niveau de ces activités dans les eaux $\left(V_{\mathrm{M}}: 1,46\right.$ à $\left.2,54 \mu \mathrm{M} \cdot \mathrm{h}^{-1}\right)$ souligne l'importance de ce processus d'hydrolyse des protéines dissoutes tant pour la croissance bactérienne que pour le cycle de l'azote organique dissous. Dans ces eaux, le « turn over » moyen des protéines dissoutes est de 7,6 jours, et les acides aminés ainsi libérés par l'activité exoprotéolytique peuvent potentiellement supporter, en moyenne, $40 \%$ de la demande bactérienne en azote.

Mots-clés : Activité exoprotéolytique, protéine dissoute, analyse en flux continu, bactérioplancton, marais maritime.

\section{INTRODUCTION}

In marine waters, dissolved organic nitrogen (DON) represents a significant fraction of the nitrogen pool (Nixon and Pilson, 1983; Mantoura et al., 1988), comprising up to $80 \%$ of the total dissolved nitrogen in surface waters (Suzuki et al., 1985; Walsh, 1989). Although most of the DON remains unidentified
(Antia et al., 1991) we know that monomeric compounds constitute only a few percent of the DON (Gardner and Stephens, 1978; Tuschall and Brezonik, 1980). Dissolved proteins, which make up the largest identified pool of DON (Sharp, 1983; Willams, 1986), can efficiently support bacterial growth in natural waters (Hollibaugh and Azam, 1983; Hagström et al., 1984; Coffin, 1989). Proteins, however, must be 
hydrolysed to amino acids to be taken up by bacteria. Recently, sensitive methods have been proposed in order to estimatc bacterial exoproteolytic activity (Somville and Billen, 1983; Hoppe, 1983). These are based on the use of a non-fluorescent model peptide which yields a fluorescent product after hydrolysis of the peptide bond by proteolytic enzymes. The first results obtained by this approach support the importance of the proteolytic pathway in cnabling bacterial growth (Hopne et al., 1988 a; Lancelot and Billen, 1984; Chróst, 1990) and in DON cycling.

Along the French Atlantic coast, shallow marine ponds cover several thousand hectares of salt marshes. In these ponds, bacterial abundance $\left(10^{6}\right.$ to $10^{7}$ cells. $\mathrm{ml}^{-1}$ ) is one order of magnitude higher than values usually found in coastal waters (Frikha, 1989; Delmas et al., 1992). These bacteria can grow efficiently on dissolved frec amino acids (Frikha, 1989) but it was not known if the high concentration of DON recorded in these ponds (ca. $40 \mu \mathrm{M}$, Robert et al., 1982) contributes significantly to bactcrial growth.

The aim of this study was to investigate, in marine pond water, the significance of bacterial exoprotcolytic activity in relation to both the DON pool (mainly dissolved combined amino acids) and bacterial growth. For this purpose, the previously manual detcction of the fluorescent compound liberated by excproteolytic activity (EPA) has been automated using flow injection analysis (FIA), thus reducing the time of analysis and improving both reproducibility and sensitivity of the measurements.

\section{METHODS}

This study was carried out in a newly dug pond $\left(70 \mathrm{~cm}\right.$ deep, $200 \mathrm{~m}^{2}$ ) at the CREMA-L'Houmeau experimental site (on the west Atlantic coast of France near La Rochelle). This pond was filled with seawater on the 8 October 1991 at high tide and emptied three weeks later. During this period of batch growth, water temperature was monitored and sampling carried out daily at 9 a.m. Within $20 \mathrm{~min}$ of collection, samples for determination of DON, dissolved combined and dissolved free amino acids (DCAA, DFAA) were filtered by gravity through precombusted glass fibre filters (GF/F), using filter holders and syringes, and immediately frozen. DON was determinated as nitrate (Strickland and Parsons, 1972) after in-line photochemical oxidation (UVpersulfate) with a Skalar continuous flow analyser. Urea analyses were performed with a continuous flow analyser according to the protocol of Koroleff (1983). DFAA measurements were carried out by flow injection analysis with o-phthaldialdehyde (Delmas et al., 1990) using glycine as the standard. DCAA were estimated by measuring amino acids released after acid hydrolysis ( $\mathrm{HCl} 5.8 \mathrm{~N}, 20$ hours at $105^{\circ} \mathrm{C}$ ) and neutralization. Bacteria were enumerated by direct counting after staining with DAPI (Porter and Feig,
1980) in subsamples taken from $18 \mathrm{ml}$ samples of pond water fixed with borate buffered formalin ( $2 \%$ final concentration). Bacterial production was determined by measuring incorporation of ${ }^{3} \mathrm{H}$-methyl thymidine (40-60 Ci.mmol, 20 nM final concentration) (Fuhrman and Azam, 1982). The rates of ${ }^{3} \mathrm{H}$-methyl thymidine incorporation into DNA were converted into cell production using $2.18 \times 10^{18}$ cells produced per mole of thymidine incorporated, then values were converted into bacterial carbon production assuming a cell content of $16 \mathrm{fg} \mathrm{C}$ (Frikha, 1989).

\section{Measurement of the proteolytic activity}

Hydrolysis of the non-fluorescent protein model substrate (L-Leucine-4-methyl-7-coumarinylamide, LLMCA), that yield the lluorescent, 4-methyl-7coumarinylamine (MCA), was used to measure exoproteolytic activity (Hoppe, 1983; Chróst et al., 1989). Samples were always processed within minutes of collection.

In a preliminary experiment, the kinetics of LLMCA hydrolysis versus time were studied in order to establish a suitable incubation time for this pond bacterial community. For all other experiments, four concentrations of LLMCA were used to estimate the kinetic parameters of the cxoprotcolytic activity $\left(K_{M}, V_{M}\right) .50 \mu l$ of $5,10,20$ and $40 \mathrm{mM}$ LLMCA solutions, prepared according to Hoppe (1983), were added to $2 \mathrm{ml}$ of water samplc (two replicates and one autoclaved control) yielding final LLMCA concentrations of $125,250,500$ and $1000 \mu \mathrm{M}$. Then, all the samples were incubated at $20^{\circ} \mathrm{C}$ in the dark. The substrate hydrolysis was terminated by cooling the test tubes in ice. The kinetic parameters $\left(V_{M}\right.$ and $K_{M}$ ) were calculated from the regression line of the Lineweaver-Burke transformation of the MichaclisMenten equation (Wright and Hobbie, 1966).

On some occasions, the microplanktonic community was separated into three fractions, $<0.2 \mu \mathrm{m},<1 \mu \mathrm{m}$, $<3 \mu \mathrm{m}$, by differential filtration through Nuclepore membrane filters at minimum vacuum pressure $(<10 \mathrm{~mm} \mathrm{Hg})$ in order to assess which fraction of the community was associated with the exoproteolytic activity.

Chróst and Velimirov (1991) reported that incubated samples could be storcd frozen $\left(-20^{\circ} \mathrm{C}\right)$ before measurements without changing the cnzyme kinetic parameters. As this storage possibility could be useful in the field, we tested (i) the influence of freezing alone and (ii) the combined effect of freezing after filtration through $0.2 \mu \mathrm{m}$ Nuclepore filters, in order to remove microorganisms, on the enzyme kinetics.

\section{Flow injection analysis of the fluorescent MCA}

Flow injection analysis of the MCA released by enzymatic hydrolysis of the non-fluorescent substrate was carried out using a high performance liquid 
chromatographic equipment (HPLC). The HPLC system consisted of a pump (Kontron, model 414), an injection valve (Beckman, model 210) and a spectrofluorescence detector (Kontron, model SFM 25). Data were recorded by an HPLC computer (Kontron, model MT450). Fluorescence was measured using excitation at $380 \mathrm{~nm}$ and emission at $440 \mathrm{~nm}$. For the flow injection analysis (FIA) Teflon tubing ( $1.5 \mathrm{~m}$ long, $0.3 \mathrm{~mm}$ I.D.) was used to connect the injection valve with the detector. A buffered solution (0.1 $\mathrm{M}$ boric acid $\mathrm{pH} 10$ ) was delivered by the pump at a flow rate of $1 \mathrm{ml}^{\mathrm{min}}{ }^{-1}$ and full loops of samplc $(20 \mu \mathrm{l})$ were directly injected. For each sample three replicate injections were carried out. MCA solution prepared according to Hoppe (1983) was used as the reference standard.

\section{RESULTS AND DISCUSSION}

\section{Flow injection analysis}

The flow injection analysis allowed at least 40 samples to be processed per hour with triplicatc injections for each sample (fig. 1a). The relative standard deviation was below $3 \%$ for $0.2 \mu \mathrm{M}$ MCA standard and better than $1 \%$ for higher concentrations. Using a low voltage for the photomultiplier tube $(\mathrm{PM}$, c.g. $370 \mathrm{~V})$ the detection limit was at the sub-micromolar level; however, sensitivity can be increased to the nanomolar level using a higher voltage for the PM tube (upper limit $900 \mathrm{~V}$ ). During our survey, the same standard solutions were analysed eleven times (10 repeated freezing and thawing processes). The results obtained show that the detection was linear over a range of two orders of magnitude ( $f$ ig. $1 b$ ), and that the relative standard deviation, which integrates day-to-day variations of the standard and that of the analytical process, was below $6 \%$. This demonstrates the stability of the fluorescent MCA solution during freezing; therefore, samples can be stored following incubation if enzymatic activity can be inhibited.

The kinetics of LLMCA hydrolysis were linear, at least over 100 minutes, while values measured for the autoclaved control remained constant (fig. 2). Significant hydrolysis was observed over the first $60 \mathrm{~min}$, indicating that the long incubation times generally used (3 to 10 hours; Hoppe, 1983; Chróst et al., 1989) were long for our samples; moreover, shorter incubation times should reduce resultant perturbation of the microbial community.

A typical record of the change in relative fluorescence versus substrate concentration (fig. 3) shows the excellent reproducibility between replicates. If we consider all the samples analysed during this study, the mean relative standard deviations between duplicates were $1.3,0.69,0.58$ and $0.56 \%$ for final LLMCA concentrations of $125,250,500$ and $1000 \mu \mathrm{M}$, respectively.
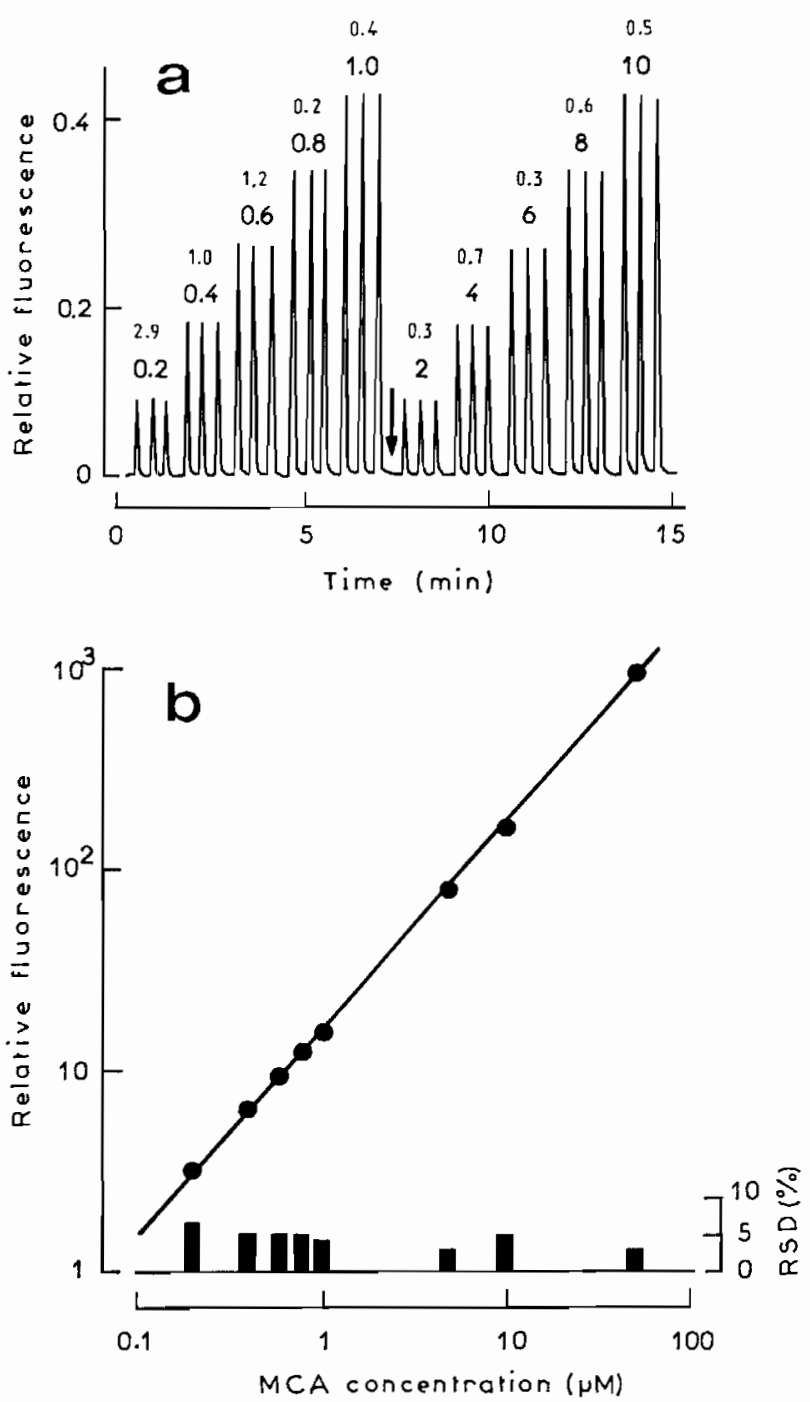

Figure 1. - Calibration of the flow injection analysis method. a: Record of fluorescent 4-methyl-7-coumarinylamine (MCA) standards, the first number inserted above the response corresponds to MCA concentration $(\mu \mathrm{M})$, the second number is relative standard deviation (\%). Arrow indicates a 10-fold signal attenuation. b: Log-log plot of the relative fluorescence versus MCA concentration and precision of the measurements (relative standard deviation: RSD \%) obtained for eleven daily calibrations with the same standard solutions.

\section{Effect of preservation and storage of the incubated sample on the enzyme activity estimations}

In contrast to the results of Chróst and Velimirov (1991) sample freezing $\left(-20^{\circ} \mathrm{C}\right)$ was not sufficient to stop LLMCA hydrolysis as $\mathrm{V}_{\mathrm{M}}$ continued to increase $(+41 \%)$ during the storage period (fig. 4). Filtration of the sample through $0.2 \mu \mathrm{m}$ pore size Nucleopore membrane filter after incubation and before freezing improved the stability of the initial $\mathrm{V}_{\mathrm{M}}$ (+11.6\% in 15 days) possibly because most of the enzymes (up to $94 \%$ ) which hydrolyse LLMCA are particle-bound (Hoppe, 1983; Rego et al., 1985; Rosso and Azam, 1987). These results suggest that 


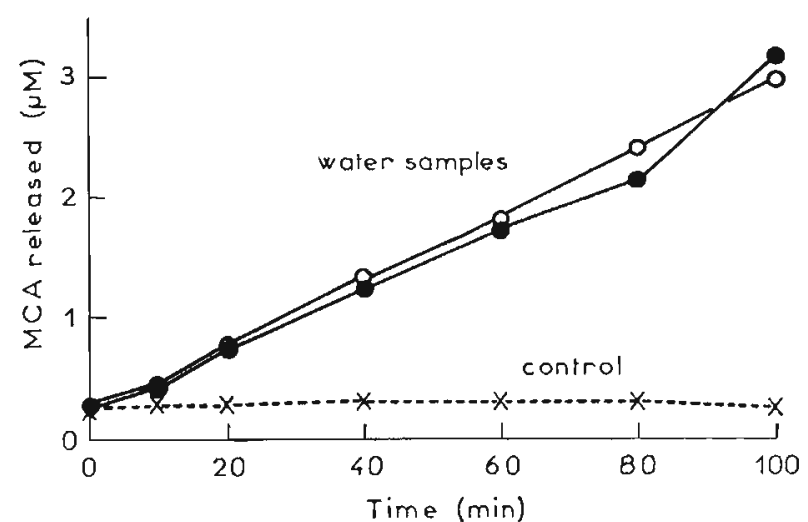

Figure 2. - Kinetics of MCA released in autoclaved control and in natural pond water (two replicates) after addition of the substrate.

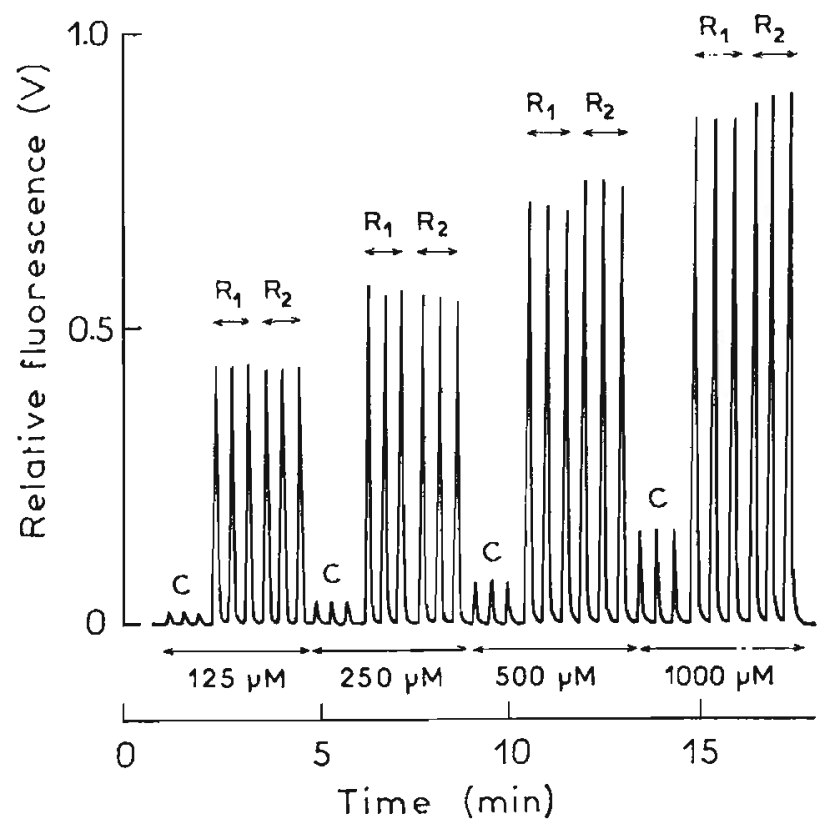

Figure 3. - Typical record of exoproteolytic activity measurement in pond water versus substrate concentration $(125,250,500$ and $1000 \mu \mathrm{M}$ final concentration). For each substrate concentration one autoclaved control (C) and two replicates $\left(R_{1}, R_{2}\right)$ were analysed by FIA with triplicate injections.

it should be feasable to store incubated samples before measurement, but further studies are needed in this respect. Other preservative treatments should also be investigated, such as physical and chemical denaturation of proteolytic enzymes (temperature, sodium dodecyl sulfate, etc.) as well as inhibition of the activity by protease inhibitors.

\section{Field study in a coastal pond}

During our survey, dissolved organic nitrogenous compounds showed no significant change with time. DON and DCAA varied from 11.4 to $15 \mu \mathrm{M}$ and from 2.5 to $3.3 \mu \mathrm{M}$, respectively. DFAA and urea were less

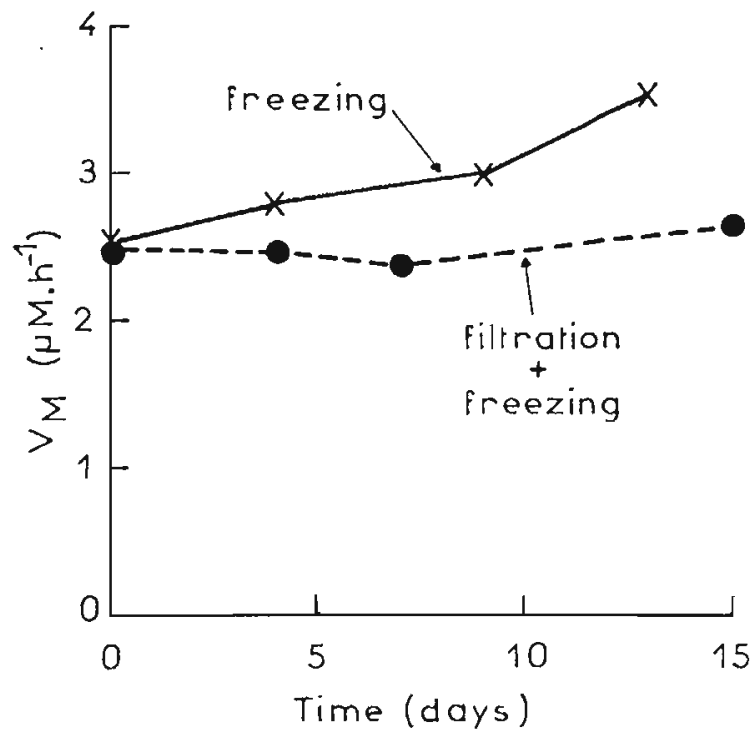

Figure 4. - Effect of the treatment of the incubated samples (freezing or filtration before freezing) before storage on the exoproteolytic activity $\left(\mathrm{V}_{\mathrm{M}}\right)$.

Table 1. - Mear concentrations of dissolved organic nitrogen (DON), urea, dissolved free amino acids (DFAA), dissolved combined amino acids (DCAA) and unidentified dissolved organic nitrogen (uDON) in pond water samples; $n=17$, sd: standard deviation.

\begin{tabular}{cccccc}
\hline & DON & Urea & DFAA & DCAA & uDON $^{(a)}$ \\
\hline mean $(\mu \mathrm{M})$ & 12.8 & 0.4 & 0.42 & 2.83 & 9.1 \\
$\mathrm{sd}$ & 0.9 & 0.3 & 0.10 & 0.21 & 1.1 \\
$\min$ & 11.4 & 0.0 & 0.30 & 2.50 & 6.9 \\
$\max$ & 15.0 & 0.9 & 0.67 & 3.34 & 11.6 \\
$\% \mathrm{DON}$ & 100 & 3.4 & 3.3 & 22.2 & 71.1 \\
\hline
\end{tabular}

(a) $\mathrm{uDON}=\mathrm{DON}-(\mathrm{Urea}+\mathrm{DFAA}+\mathrm{DCAA})$.

abundant, typically being in the range 0.3 to $0.67 \mu \mathrm{M}$ for amino acids, and 0 to $0.93 \mu \mathrm{M}$ for urea (table 1). DFAA represented only a small part $(\approx 3.3 \%)$ of DON while DCAA constituted the largest identified part $(\approx 22 \%)$; up to $71 \%$ of the DON was unidentified. These results are in agreement with those of previous studies (Gardner and Stephens, 1978; Sharp, 1983; Williams, 1986). Bacterial abundance varied between $7 \times 10^{6}$ and $20 \times 10^{6}$ cells.ml $^{-1}$ and estimates of production between 29 and $79 \mu \mathrm{g} \mathrm{C} . \mathrm{I}^{-1} . \mathrm{d}^{-1}$ (table 2); these values are typical for these ponds during autumn (Frikha, 1989; Delmas et al., 1992). The absence of bacterial blooms during this stalling period agrees with previous observations, that large increases in bacterial biomass only occur when water temperatures exceed $15^{\circ} \mathrm{C}$ (Delmas et al., 1992). Maximal rates of protein hydrolysis were in the range 1.46 to $2.54 \mu \mathrm{M} . \mathrm{h}^{-1}$ (table 2). These rates are higher than those generally found in samples from the open sea (range: 0.001$0.690 \mu \mathrm{M} . \mathrm{h}^{-1}$; Rosso and Azam, 1987; Hoppe et 
Table 2. - Summary values for water temperature (T), bacterial number (Bact, $10^{6}$ cells. $\mathrm{ml}^{-1}$ ), bacterial production (Prod, $\mu \mathrm{g}$ C..$^{-1} \cdot$ day $\left.^{-1}\right)$, and exoproteolytic activity $\left(V_{M}, \mu M \cdot h^{-1}\right)$, number of measurements; sd: standard deviation.

\begin{tabular}{crrll}
\hline & $\mathrm{T}$ & Bact & Prod & $\mathrm{V}_{\mathrm{M}}$ \\
\hline $\mathrm{n}$ & 17 & 17 & 15 & 17 \\
mean & 13.3 & 11.2 & 55.5 & 1.99 \\
$\mathrm{sd}$ & 2.1 & 3.7 & 14.6 & 0.33 \\
$\min$ & 10.1 & 6.9 & 29.5 & 1.46 \\
$\max$ & 16.4 & 20.3 & 79.4 & 2.54 \\
\hline
\end{tabular}

al., 1988) but they are similar to the maximum rates reported for coastal marine waters (range: 0.06$1.90 \mu \mathrm{M} \cdot \mathrm{h}^{-1}$; Lancelot and Billen, 1984) and for

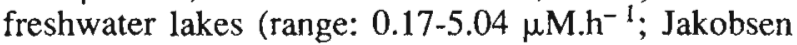
and Rai, 1991).

Size fractionation of the microbial community through $0.2,1.0$ and $3 \mu \mathrm{m}$ pore size Nucleopore filters showed that most of the exoproteolytic activity was associated with the bacterial sized fraction $(>75 \%$, fig. 5). Proteolytic activity in the $<0.2 \mu \mathrm{m}$ fraction was insignificant, as usually found for marine waters (Hollibaugh and Azam, 1983; Rego et al., 1985; Rosso and Azam, 1987). The fact that maximum rate of hydrolysis $\left(\mathrm{V}_{\mathrm{M}}\right)$ was correlated with bacterial abundance $(\mathrm{r}=0.575, \mathrm{n}=17, p<5 \%)$ also indicates that bacteria were responsible for the proteolytic activity.

Estimates of cell-specific enzyme activity ranged between 110 to $270 \mathrm{pmol}^{-10^{-6}}$ cells. $^{-1}$. They were higher than generally found for bacteria from the open sea (range: $10-70$ pmol.10 ${ }^{-6}$ cells. $\mathrm{h}^{-1}$; Hoppe, 1983; Rosso and Azam, 1987) but within the range reported for bacteria from lakes, rivers and marine lagoons (range: $100-600$ pmol.10-6 cells. ${ }^{-1}$; Chróst et
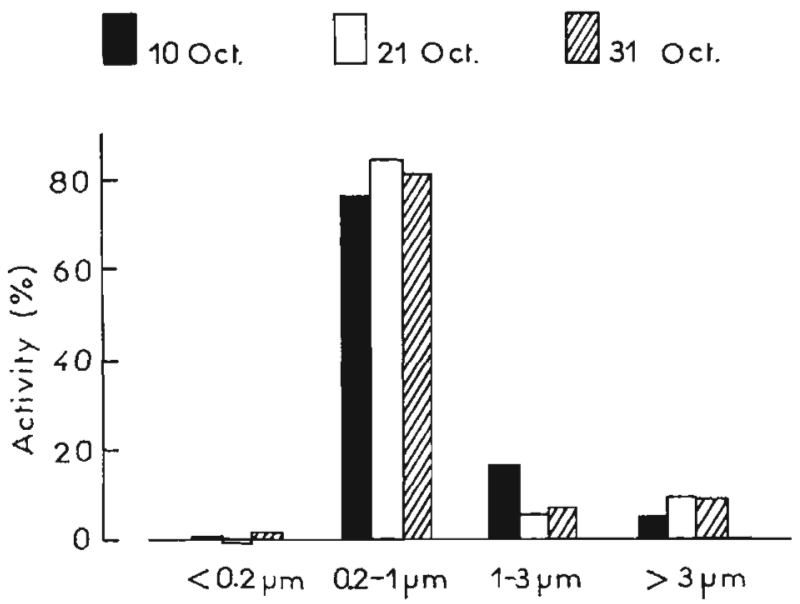

Figure 5. - Proteolytic activity (\% total) in size fractionated pond water samples.

Vol. $7, n^{\circ} 1-1994$ al., 1989; Hoppe et al., $1988 b$; Admiraal and Tubbing, 1991). As the availability of DON regulates both the synthesis and activity of microbial exoenzymes (Chróst, 1991), the high specific exoproteolytic activities found may reflect the ability of the bacterial community either to hydrolyse polymeric amino compounds or to take them up, or both.

LLMCA is hydrolysed not only by leucine peptidase but also by other amino peptidases (Hoppe et al., $1988 a$; Chróst, 1991). Hydrolysis rates of the Lleucine model substrate could thus be a good estimate of the hydrolysis rate of natural dissolved peptides and proteins (Rego et al., 1985; Rosso and Azam, 1987). As the in situ concentrations of DCAA are known, as is the effect of water temperature on hydrolysis rate $\left(\mathrm{Q}_{10}: 1.9\right.$ to 2.4 , Hoppe, 1983; Rosso and Azam, 1987; this study, $Q_{10}: 1.93$ to 2.05 , results not shown) we can estimate the hydrolysis rates in situ using the Michaelis-Menten equation. These calculations suggest that in situ hydrolysis rates varied between 0.25 and $0.56 \mu \mathrm{M}$ per day (mean value: $0.39 \mu \mathrm{M} \cdot$ day $^{-1}, \mathrm{n}=17$ ). If these estimates are correct, the amount of monomeric compounds liberated daily by hydrolytic activity could be similar to the measured DFAA concentrations $(0.3$ to $0.67 \mu \mathrm{M})$. Thus exoproteolytic activity could supply either a large source of DFAA or a significant source of nitrogen for bacterial growth. These in situ hydrolysis rates may be underestimated because the test may not have measured all the exoproteolytic activity and the $K_{M}$ of the model substrate is significantly higher than that of indigenous dissolved proteins (Fontigny et al., 1987). Despite these uncertainties, the in situ rate estimates are similar to those reported by Coffin (1989) for the Delaware estuary during winter (mean value: $1.51 \mu \mathrm{M} \cdot \mathrm{d}^{-1}$ ). Bacterial abundance was correlated with the estimated in situ exoproteolytic activity (fig. 6, $\mathrm{r}=0.75, \mathrm{n}=17, p<0.1 \%$ ); moreover, in situ activity correlated with bacterial production $(\mathrm{r}=0.54, \mathrm{n}=15 ; p<5 \%)$ whereas $\mathrm{V}_{\mathrm{M}}$ did not. Although our estimates of hydrolytic activities in situ may be rather rough, they are not unrealistic as they relate significantly both to bacterial biomass and to production.

The turnover time of dissolved peptides, estimated from the Lineweaver-Burk transformation of the Michaelis-Menten equation (Wright and Hobbie, 1966), varied between 4.9 and 11.5 days (mean value: 7.6 days), and correlated significantly with bacterial cell number $(\mathrm{r}=0.61, \mathrm{n}=17, p<0.1 \%$, fig. 7). These tumover times agree with values determinated with peptide analogues (range: 2.6116 days; Hoppe, $1988 a$ ) or with ${ }^{136} \mathrm{I}$ and ${ }^{14} \mathrm{C}$ radiolabelled dissolved proteins (range: 1-7.5 days; Hollibaugh and Azam, 1983; Coffin, 1989) in other marine environments.

Assuming a mean $\mathrm{C} / \mathrm{N}$ ratio of 4.5 (by atoms) for bacteria, we can calculate that, in terms of nitrogen, the bacterial production is in the range of 


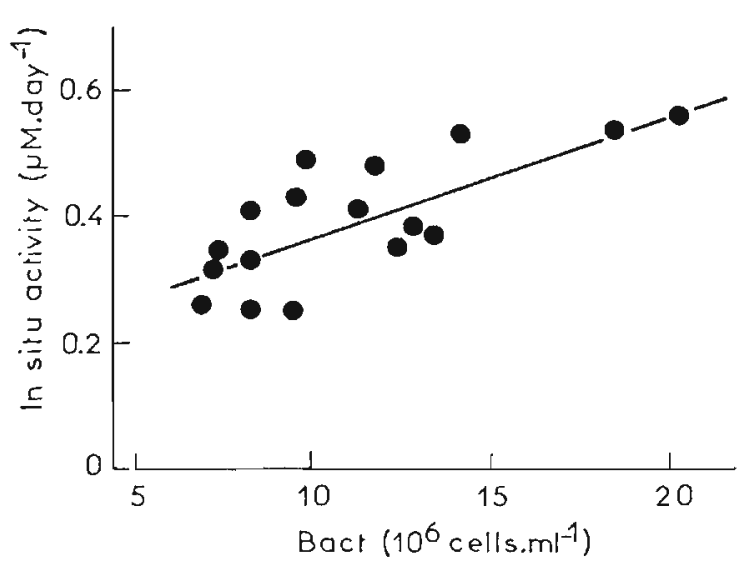

Figure 6. - Relationship between estimated exoproteolytic activity in situ and bacterial abundance.

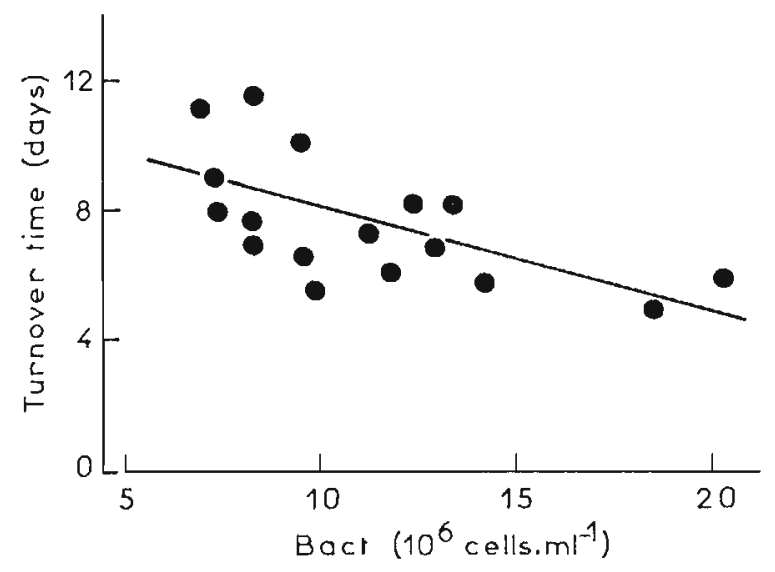

Figure 7. - Relationship between estimated turnover time of dissolved peptides and bacterial abundance.

0.55 to $1.47 \mu \mathrm{M}$. day $^{-1}$ (mean value: $1.03 \mu \mathrm{M} . d a y^{-1}$ ). Exoproteolytic bacterial activity could liberate roughly the equivalent of 0.25 to $0.56 \mu \mathrm{M}$ of nitrogen per day as free monomeric compounds. We have some evidence that amino acids derived from protein hydrolysis are preferentially utilized by bacteria and do not accumulate in the medium (Hollibaugh and Azam, 1983). Thus, we can estimate, assuming 100\% transfer efficiency, that the organic nitrogen provided by exoproteolytic activity could potentially fulfill $41 \%$ of the bacterial nitrogen demand for growth (range: 25 to $68 \%$ ). As actual growth of bacteria on natural DCAA is unknown we cannot state if these estimates are realistic. However, these results, as those obtained in other environments, suggest the importance of this pathway for transforming non-directly utilizable polymeric DON into readily assimilable free monomers.

In order to increase rearing production in coastal marine ponds, experiments to stimulate primary production by adding fertilizer are in progress (Hussenot, 1992). These manipulations of the food webs can lead to significant increases in the standing stock of DON (Legrand, 1993). Bacterial biomass, exoproteolytic activity and production are all likely to be augmented by increasing the production of DON. Consequently, in any experiment which stimulates primary production, the effect of this stimulation on their bacterial community must be considered, particularly as, in these ponds, the bacterioplankton constitutes a significant fraction of the particulate organic carbon (Delmas et al., 1992) which is transferred to higher trophic levels via the microheterotrophic food chain (Frikha and Linley, 1988/1989).

\section{CONCLUSION}

Flow injection analysis allows measurement of exoproteolytic activity with good analytical sensitivity and reproducibility. This method can be easily adapted to determine other enzymatic activities by using specific fluorogenic substrates (e.g. glucosidase, phosphatase). Our preliminary investigations on the storage of incubated samples yielded promising results and deferred sample analysis would be useful for field studies. In marine pond water, exoproteolytic activity was well correlated with bacterial biomass and production. The high level of exoproteolytic activity measured in pond water suggests that dissolved polymeric material is important for bacterial growth and in the cycling of dissolved organic nitrogen. In spite of the quantitative importance of dissolved peptides and proteins, their chemical characteristics, such as molecular weight distribution, remain poorly known as are their rates of hydrolysis and uptake by the microbial community. In order to study these chemical and biodynamic parameters, we are investigating analytical methods to characterize dissolved proteins quantitatively according to their molecular weight.

\section{Acknowledgements}

We thank Mrs F. Momet for nutrient analysis and Dr I. Jenkinson (ACRO, La Roche Canillac) for improving the English version. 


\section{REFERENCES}

Admiraal W., G. M. J. Tubbing, 1991. Extracellular enzyme activity associated with suspended matter in the River Rhine. Freshw. biol., 26, 507-517.

Antia N. J., P. J. Harrison, L. Oliveira, 1991. The role of dissolved organic nitrogen in phytoplankton nutrition, cell biology and ecology. Phycologia, 30, 1-89.

Chróst R. J., 1990. Microbial ectoenzymes in aquatic environments. In: Aquatic microbial ecology: biochemical and molecular approaches. J. Overbeck, R. J. Chróst eds., Springer-Verlag, New York, 47-78.

Chróst R. J., 1991. Environmental control of the synthesis and activity of aquatic microbial ectoenzymes. In: Microbial enzymes in aquatic environments. R. J. Chróst ed., Springer-Verlag, New York, 29-59.

Chróst R. J., U. Münster, H. Rai, D. Albrecht, P. K. Witzel, J. Overbeck, 1989. Photosynthetic production and exoenzymatic degradation of organic matter in the euphotic zone of a eutrophic lake. J. Plankton Res., 11, 223-242.

Chrost R. J., B. Velimirov, 1991. Measurement of enzyme kinetics in water samples: effect of freezing and soluble stabilizer. Mar. Ecol. Prog. Ser., 70, 93-100.

Coffin R. B., 1989. Bacterial uptake of dissolved free and combined amino acids in estuarine waters. Limnol. Oceanogr., 34, 531-542.

Delmas D., M. G. Frikha, E. A. S. Linley, 1990. Dissolved primary amine measurement by flow injection analysis with o-phthaldialdehyde: comparison with highperformance liquid chromatography. Mar. Chem., 29, 145-154.

Delmas D., M. G. Frikha, H. Reymond, E. A. S. Linley, Y. Collos, 1992. Long term microbial community dynamics in a coastal marine pond. Mar. Microb. Food Webs, 6, 39-54.

Fontigny A., G. Billen, J. Vives-Rego, 1987. Some kinetic characteristics of exoproteolytic activity in coastal seawater. Est. Coast. Shelf Sci, 25, 127-133.

Frikha M. G., 1989. Rôle des bactéries dans le réseau trophique et les processus de minéralisation d'un marais atlantique type claire à huîtres. Thèse dr. Univ. Bretagne Occidentale, Brest, $128 \mathrm{p}$.

Frikha M. G., E. A. S. Linley, 1988/1989. Predation on bacterioplankton in oyster ponds of the Atlantic coast of France. Mar. Microb. Food Webs, 3, 67-78.

Fuhrman J. A., F. Azam, 1982. Thymidine incorporation as a measure of heterotrophic bacterioplankton production in marine surface waters: evaluation and field results. Mar. Biol., 66, 109-120.

Gardner W. S., J. A. Stephens, 1978. Stability and composition of terrestrially derived dissolved organic nitrogen in continental shelf surface waters. Mar. Chem., 6, 335-342.

Hagström A., J. W. Ammerman, S. Henrichs, F. Azam, 1984. Bacterioplankton growth in seawater: II. Organic matter utilization during steady-state growth in seawater cultures. Mar. Ecol. Prog. Ser., 18, 41-48.

Hollibaugh J. T., F. Azam, 1983. Microbial degradation of dissolved proteins in seawater. Limnol. Oceanogr., 28, 1104-1116.

Hoppe H.-G., 1983. Significance of exoenzymatic activities in the ecology of brackish water: measurements by means of methylumbelliferyl-substrates. Mar. Ecol. Prog. Ser., 11, 299-308.
Hoppe H.-G., S.-J. Kim, K. Goke, 1988 a. Microbial decomposition in aquatic environments: combined process of extracellular enzyme activity and substrate uptake. Appl. Environ. Microbiol, 54, 784-790.

Hoppe H.-G., W. Schramm, P. Bacolod, 1988 b. Spatial and temporal distribution of pelagic microorganisms and their proteolytic activity over a partly destroyed coral reef. Mar. Ecol. Prog. Ser., 44, 95-102.

Hussenot J., 1992. Maîtriser la stimulation de la productivité naturelle permet de proposer une aquaculture marine semiextensive dans les marais de la côte atlantique française. Aqua. Rev., 41, 31-33.

Jacobsen T. R., H. Rai, 1991. Aminopeptidase activity in lakes of differing eutrophication. In: Microbial enzymes in aquatic environments. R. J. Chróst ed., Springer-Verlag, New York, 155-164.

Koroleff F., 1983. Determination of urea. In: Methods of sea water analysis. K. Grasshoff, M. Ehrhardt, K. Kremling eds., Verlag Chemie, Weinheim, 158-162.

Lancelot C., G. Billen, 1984. Activity of heterotrophic bacteria and its coupling to primary production during the spring bloom in the southern bight of the North Sea. Limnol. Oceanogr., 29, 721-730.

Legrand C., 1993. Production primaire et bactérienne en marais maritimes: excrétion organique algale et utilisation par les bactéries. Thèse dr. Univ. Paul Sabatier, Toulouse, $189 \mathrm{p}$.

Mantoura R. F. C., N. J. P. Owens, P. H. Burkill, 1988. Nitrogen biogeochemistry and modelling of Carmarthen Bay. In: Nitrogen cycling in coastal marine environments. T. H. Blackburn, J. Sorensen eds., John Wiley \& Sons, Chichester, 415-441.

Nixon S. W., M. E. Q. Pilson, 1983. Nitrogen in estuarine and coastal marine ecosystems. In: Nitrogen in the marine environment. E. J. Carpenter, D. G. Capone eds., Academic Press, New York, 565-647.

Porter K. G., Y. S. Feig, 1980. The use of DAPI for identifying and counting aquatic microflora. Limnol. Oceanogr., 25, 943-948.

Rego J. V., G. Billen, A. Fontigny, M. Somville, 1985. Free and attached proteolytic activity in water environments. Mar. Ecol. Prog. Ser., 21, 245-249.

Robert J. M., S. Y. Maestrini, M. Héral, Y. Zanette, 1982. Production des micro-algues des claires ostréicoles en relation avec l'azote organique dissous excrété par les huîtres. Oceanol. Acta, Actes symposium international sur les lagunes côtières, SCOR/IABO/UNESCO, Bordeaux, 389-395.

Rosso A. L., F. Azam, 1987. Proteolytic activity in coastaloceanic waters: depth distribution and relationship to bacterial populations. Mar. Ecol. Prog. Ser., 41, 231-240.

Sharp J. H., 1983. The distribution of inorganic and dissolved and particulate organic nitrogen in the sea. In: Nitrogen in the marine environment. E. J. Carpenter, D. G. Capone eds., Academic Press, New York, 1-35.

Somville M., G. Billen, 1983. A method for determining exoproteolytic activity in natural waters. Limnol. Oceanogr., 28, 190-193.

Strickland J. D. H., T. R. Parsons, 1972. A practical handbook of seawater analysis. Bull. Fish. Res. Board Can., 167, 2nd ed., $310 \mathrm{p}$. 
Suzuki Y., Y. Sugimura, T. Itoh, 1985. A catalytic oxidation method for the datermination of total nitrogen dissolved in seawater. Mar. Chem., 16, 83-97.

Tuschall J. R., P. L. Brezonik, 1980. Characterization of organic nitrogen in natural waters: its molecular size, protein content, and interactions with heavy metals. Limnol. Oceanogr., 25, 495-504.

Walsh T. W., 1939. Total dissolved nitrogen in seawater: a new-high-temperature combustion method and a comparison with photo-oxidation. Mar. Chem., 25, 295-311.

Williams P. M., 1986. Chemistry of the dissolved and particulate phases in the water column. In: Plankton dynamics in the Southern California Bight. R. W. Eppley ed., Springer-Verlag, New York, 53-83.

Wright R. T., J. E. Hobbie, 1966. Use of glucose and acetate by bacteria and algae in aquatic ecosystems. Ecology, 47, 447-464. 